\title{
Audit-identified avoidable factors in maternal and perinatal deaths in low resource settings: a systematic review
}

\author{
Hasan S Merali ${ }^{*}$, Stuart Lipsitz ${ }^{2}$, Nathanael Hevelone ${ }^{2}$, Atul A Gawande ${ }^{2,3}$, Angela Lashoher $^{4}$, Priya Agrawal ${ }^{5}$ and
} Jonathan Spector ${ }^{5,6}$

\begin{abstract}
Background: Audits provide a rational framework for quality improvement by systematically assessing clinical practices against accepted standards with the aim to develop recommendations and interventions that target modifiable deficiencies in care. Most childbirth-associated mortality audits in developing countries are focused on a single facility and, up to now, the avoidable factors in maternal and perinatal deaths cataloged in these reports have not been pooled and analyzed. We sought to identity the most frequent avoidable factors in childbirth-related deaths globally through a systematic review of all published mortality audits in low and lower-middle income countries.

Methods: We performed a systematic review of published literature from 1965 to November 2011 in Pubmed, Embase, CINAHL, POPLINE, LILACS and African Index Medicus. Inclusion criteria were audits from low and lower-middle income countries that identified at least one avoidable factor in maternal or perinatal mortality. Each study included in the analysis was assigned a quality score using a previously published instrument. A meta-analysis was performed for each avoidable factor taking into account the sample sizes and quality score from each individual audit. The study was conducted and reported according to PRISMA guidelines for systematic reviews.
\end{abstract}

Results: Thirty-nine studies comprising 44 datasets and a total of 6,205 audited deaths met inclusion criteria. The analysis yielded 42 different avoidable factors, which fell into four categories: health worker-oriented factors, patient-oriented factors, transport/referral factors, and administrative/supply factors. The top three factors by attributable deaths were substandard care by a health worker, patient delay, and deficiencies in blood transfusion capacity (accounting for 688, 665 , and 634 deaths attributable, respectively). Health worker-oriented factors accounted for two-thirds of the avoidable factors identified.

Conclusions: Audits provide insight into where systematic deficiencies in clinical care occur and can therefore provide crucial direction for the targeting of interventions to mitigate or eliminate health system failures. Given that the main causes of maternal and perinatal deaths are generally consistent across low resource settings, the specific avoidable factors identified in this review can help to inform the rational design of health systems with the aim of achieving continued progress towards Millennium Development Goals Four and Five.

Keywords: Maternal, Fetal, Neonatal, Perinatal, Avoidable, Factors, Death, Mortality

\footnotetext{
*Correspondence: Hasan_Merali@post.harvard.edu

'The Hospital for Sick Children, 555 University Avenue, Toronto, ON M5G $1 \times 8$, Canada

Full list of author information is available at the end of the article
} 


\section{Background}

Devising strategies that measurably improve maternal and newborn care in low resource settings is an urgent global priority [1,2]. Nearly 300,000 maternal deaths [3], 3 million newborn deaths [4], and 1 million intrapartumrelated stillbirths [5], take place each year in grossly disproportionate geographic patterns. Given that there are many countries with very low childbirth-related mortality rates, it is clear that high childbirth-related mortality burdens are not inevitable. Rational bolstering of health systems saves lives, even in lower income settings where resources are limited.

The major complications that result in maternal, newborn, and fetal deaths are well described. For mothers, these are traditionally categorized as excessive hemorrhage, infection, hypertensive disorders, and obstructed labor [6]. For babies, these are intrapartum-related events (previously called birth asphyxia), infection, and complications of prematurity [7]. Avoidable stillbirths are largely attributed to inadequate intrapartum care [5]. These categories provide an important orientation to the general causes of childbirth-related deaths and as such are fundamental to establishing a basis for strengthening health systems. However, a limitation of these somewhat broad categorizations is insight into where exactly deficiencies in clinical care are occurring, information that is critical to the design and implementation of effective health system improvements. For example, a maternal death from hemorrhage can result from absent prophylactic oxytocin, undetected bleeding, and/or inaccessible blood transfusion capabilitythree different types of system failures that necessitate different intervention approaches to prevent failure recurrence. Targeted health system strengthening relies on a systematic analysis of the events that lead to deaths in order to determine if avoidable breakdowns in medical care are present. If such deficiencies exist, fully characterizing them and pinpointing precisely where in the clinical care continuum they occur provides clinicians, policymakers, and other stakeholders with information needed to effectively address them.

Audits are tools that provide a logical framework for quality improvement by systematically assessing clinical practices against accepted standards [8]. Mortality audits have demonstrated success in helping to reduce childbirthrelated deaths in lower income countries [9-11]. Since the main causes of maternal and perinatal deaths are consistent across lower income countries, it stands to reason that there are also similarities in the avoidable factors associated with those deaths.

Most maternal and perinatal death audits have been restricted to a single facility or region with no widely utilized centralized mechanism for aggregating data from across countries [12-14]. Up to now, the avoidable factors in deaths cataloged in these reports have not been comprehensively pooled and analyzed. We sought to identify the most frequently reported factors in avoidable childbirth-related deaths globally through a systematic review of all published reports of mortality audits in low and lower-middle income countries. Our main objectives were to identify those factors that repeatedly account for high proportions of avoidable maternal and perinatal deaths in individual audits as well as to identify the avoidable factors that contribute to the most deaths overall.

\section{Methods \\ Eligibility}

Studies from low and lower-middle income countries were considered, using World Bank criteria for stratification of country by gross national income (GNI) per capita [15]. Studies were eligible if they performed an audit of maternal or perinatal deaths using medical records, meetings of health workers, and/or interviews of health workers or patient families. Studies had to explicitly identify at least one avoidable factor in a maternal or perinatal death, and studies had to utilize definitions for maternal and perinatal deaths that were reasonably similar to those used by WHO. Maternal deaths are defined by WHO as "the death of a woman while pregnant or within 42 days of termination of pregnancy, irrespective of the duration and site of the pregnancy, from any cause related to or aggravated by the pregnancy or its management but not from accidental or incidental causes" [16]. The perinatal period, as defined by the WHO, "commences at 22 completed weeks (154 days) of gestation and ends seven completed days after birth" [17]. Perinatal mortality refers to stillbirths and newborn deaths in the first week of life [17]. For the purpose of this analysis, a factor in an "avoidable death" was defined as one that was assessed to be directly related to the death; in other words, if the factor had been avoided than the death would probably not have occurred [18]. Audits that did not report specific avoidable causes in maternal and/or perinatal deaths were excluded. Two investigators (HSM and JS) determined the eligibility of the articles independently and any discrepancy was resolved by a discussion between these two investigators.

\section{Search strategy}

We performed a systematic search of published literature from 1965 to November 2011 in Pubmed, Embase, CINAHL, POPLINE, LILACS and African Index Medicus. The search strategy included various combinations of exploded and focused MeSH headings and keyword searching using the terms Perinatal, Maternal, Mothers, Neonatal, Newborn, Infant, Mortality, Audit, Clinical Audit, Death, Fatal Outcome, Avoidable, Preventable, and Developing Countries. A previously described "snowball" search strategy was also performed in which papers were 
identified through bibliographies of key studies [19]. We also attempted to identify additional relevant studies, in particular non-published datasets, through queries to experts and international organizations concerned with maternal and perinatal health. Articles in all languages were considered and translated when necessary.

\section{Quality scoring}

Each article that met inclusion criteria was assigned a quality score in order to impose a weighing scheme according to the quality of the study. The score, developed to analyze the quality of obstetrical care in low and middle income countries [20], utilizes a numerical scale ranging from zero (lowest quality) to nine (highest quality). Calculation of the quality score was conducted by assessing the following criteria: selection of audit cases (maximum 3 points), quality control during the audit process (maximum 4 points), and reliability of the audit (maximum 2 points) (See Nine-point clinical audit quality criteria). Two investigators (HSM and JS) independently scored each audit by assigning one point for each criterion met by the article. If there was a discrepancy between the scores of the two investigators, the two scores were averaged to arrive at a final score.

\section{Nine-point clinical audit quality criteria adapted from} Pirkle et al. [20].

Selection of cases

Description of study population with clear case definition

Description of sampling strategy

Consideration of missing cases

Data quality control

Criterion-based clinical audit pilot or pre-tested

Description of staff profile

Training of staff

Data entry validity checks

Reliability

Standardized data collection form

Inter-observer/inter-site variability assessed

\section{Statistical analysis and reporting}

A meta-analysis was performed for each avoidable factor identified. First, we calculated the percent of studies where the factor was determined to be a cause of a maternal or perinatal death. Next, for those studies where the factor was determined to be a cause of death, a "pooled" or combined estimate of the percentage of deaths in those studies due to the factor was calculated. The pooled estimate was calculated using a weighted average of the estimates from the individual studies via accepted meta-analysis techniques [21,22], in which the study is treated as a random effect. We estimated the weighted averages, confidence intervals for the weighted averages, and the variance of the random study effect using an iteratively reweighted least squares approach [21]. The weights used in the iteratively reweighted least squares approach takes into account the sample size from each individual study, the variance of the random study effect, and the quality score of each study. This approach is semi-parametric in that is gives unbiased estimates regardless of the type of outcome variable (continuous, categorical or percentages). Finally, we determined the total number of attributable deaths for each avoidable factor. The study was conducted and reported according to PRISMA guidelines [23], (See Additional file 1). All analyses were performed using SAS/ STAT 9.3 (SAS Institute, Cary, NC, 2011).

\section{Results}

\section{Search results}

The search returned 3,775 results and an additional 16 papers were added from reference lists. There were 691 duplicate entries and 2,975 were subsequently removed after abstract screening. The full texts of the 125 remaining articles were reviewed and 39 met inclusion criteria (Figure 1). These 39 studies included a total of 44 datasets since five studies included multiple datasets; one study included datasets from two different time periods [24], one study included datasets from two different countries [25], and two studies included datasets from both maternal and perinatal populations $[24,26]$. Two other studies analyzed deaths from different time periods $[27,28]$ but the time periods were contiguous in these studies and so they were considered as one dataset each. We were unable to identify unpublished audits of maternal and newborn deaths that met inclusion criteria. Therefore, only published data were used. We summarized

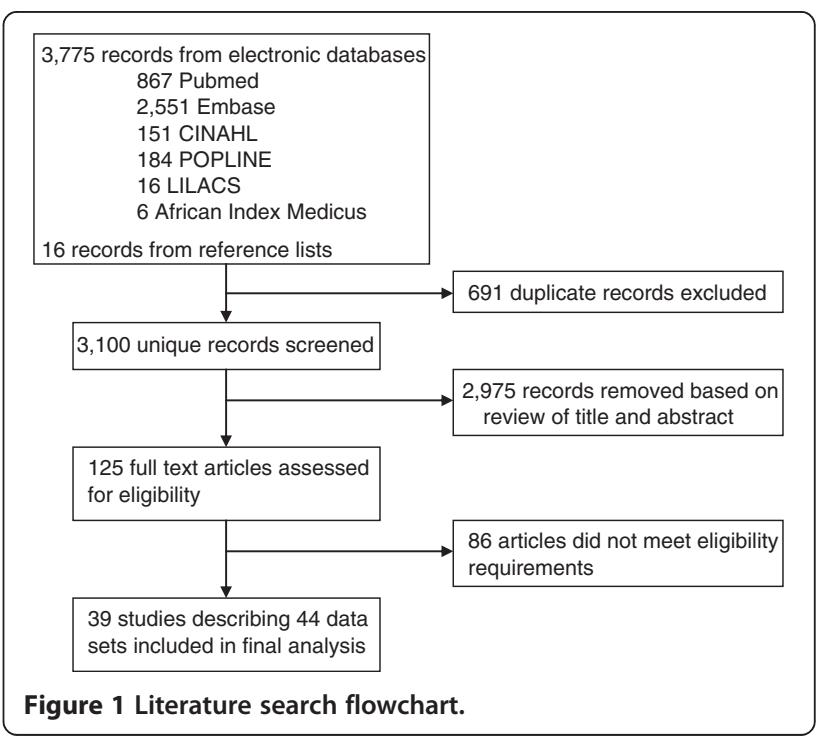


the datasets and categorized them by type of measure examined [24-62] (Table 1).

\section{Dataset characteristics}

Forty-four datasets were included in the study, comprising a total of 6,205 audited deaths. The majority of the datasets, $82 \%$, came from African studies. Two datasets (4.5\%) were from Pakistan [48,61], two (4.5\%) from Indonesia $[25,30]$, and four (9.1\%) from India [24]. Of note, the four datasets from India were obtained from the same investigation [24]. The oldest dataset was from 1967 [24] and the most recent datasets were from 2009 [47,62]. Thirty-one of the 44 datasets (70.5\%) examined maternal deaths while the other 13 datasets $(29.5 \%)$ examined perinatal deaths. Study methods varied and there were an equal number of datasets that employed prospective methods $(45.5 \%)$ as those that used retrospective methods (45.5\%). Four of the datasets $[27,45,48,56](9.1 \%)$ used a combined retrospective and prospective methodology. The majority of the datasets, $72.7 \%$, described hospital populations, while the remaining $27.3 \%$ described both hospital and community populations. Many of the studies reported the maternal mortality rate and perinatal mortality rate from their audited populations, and these varied between studies. Just under half of the studies (47.7\%) estimated the percentage of deaths that were thought to be avoidable in the sample audited, and this ranged from $1.5 \%$ to $88 \%$. Quality scores for the audits ranged between 2-8 (See Table 1).

\section{Avoidable factors}

Overall there were 42 avoidable factors in maternal and perinatal deaths identified from the 44 datasets. These 42 factors fell into four general categories: health worker-oriented factors were the most common, accounting for 28 (66.7\%) of the 42 factors; the next most common, in descending order of frequency, were patientoriented factors (14.3\%), administrative/supply factors (11.9\%), and transport/referral factors (7.1\%). All of the factors are summarized by category in Table 2 (within each category, factors are listed in order of relative number of attributable deaths).

The top 10 avoidable factors, listed in order of attributable deaths, are shown in Table 3. The number of deaths attributable to these factors ranged between 251 - 688 of the total sample of 6,205 audited deaths. Each of the top 10 avoidable factors was reported in a maternal or perinatal death in $10-23(22.7 \%-52.3 \%)$ of the datasets. The most common factors reported overall were patient and transport delays, each of which was a reported factor in $52.3 \%$ of the datasets. Health care worker-oriented factors were the most common category of factors among the top 10 factors, accounting for six out of ten factors. Substandard health worker practice was responsible for the most deaths (688 deaths), and we estimated that this factor contributed to $28.5 \%$ of the deaths in datasets where it was identified as an avoidable factor (See Additional file 2).

\section{Discussion}

To our knowledge, this is the first systematic review of avoidable factors in global maternal and perinatal deaths identified by mortality audits. Numerous avoidable factors were identified and found to be related to the behaviors and practices of both health workers and patients, as well as to administrative, supply, referral and transport problems. Chronologically, factors took place across the continuum of childbirth from the antenatal period, through labor and delivery, and into the postpartum and postnatal periods, though the majority of factors were clustered in the intrapartum period.

The most important avoidable factor by attributable deaths was substandard practice by health workers. While it would have been beneficial for audits to describe more precisely the specific substandard practices, there remains value in knowing that the majority of deaths were thought to have been avoidable if health workers performed better. This has implications for current strategies focused on assuring the presence of skilled health workers at every delivery, including campaigns that incentivize women to deliver in health facilities [63-66]. Our data are consistent with the idea that the presence of health workers at deliveries does not alone ensure the safe care of women and newborns. Adequate health worker training is vital and, presumably, so too are refresher courses and patient safety and quality initiatives that help to ensure that minimum standards of care are reliably delivered by health workers at each and every birth. While the audits specifically refer to substandard health worker practice, future work might include efforts to better understand how health care workers are supported or disempowered by the larger health system.

The second most important avoidable factor by attributable deaths was patient delay. Cultural issues and failure by women and their communities to recognize danger signs proved to be significant factors in maternal and perinatal deaths. Detailed descriptions of the specific reasons for patient delay in the studies included delays due to decision-making control by the 'head of household, childcare concerns for other children in the family, mistrust of the health system, and peer pressure by other members of the community. The data suggest that education in the antenatal period should not be reserved for women alone, but also made available to other members of her family and even the community-at-large, parties which may exert influence over the timing of the woman's presentation to skilled care. This is supported by a recent study in Kenya that also found strong a strong link between 
Table 1 Summary of study datasets $(n=44)$

\begin{tabular}{|c|c|c|c|c|c|c|c|c|}
\hline Authors & Country & Year & Population & $\begin{array}{l}\text { Mortality rate/ } \\
\text { ratio in sample }\end{array}$ & $\begin{array}{l}\text { No. of } \\
\text { audits }\end{array}$ & $\begin{array}{l}\% \text { avoidable } \\
\text { mortality }\end{array}$ & Methods & Quality score \\
\hline $\begin{array}{l}\text { Ozumba BC, Nwogu-lkojo } \\
\text { EE [29] }\end{array}$ & Nigeria & $2003-2005$ & Maternal & $2,397 / 100,000$ & 47 & 70 & $\begin{array}{l}\text { Retrospective case record review at a } \\
\text { university-associated tertiary care hospital }\end{array}$ & 4 \\
\hline $\begin{array}{l}\text { Suprakito G, Wirth ME, Achadi } \\
\text { E [30] }\end{array}$ & Indonesia & 1998-1999 & Maternal & - & 130 & - & $\begin{array}{l}\text { Prospective case record review, staff interviews, } \\
\text { and verbal autopsy in } 3 \text { districts comprising } 5 \\
\text { hospitals and } 55 \text { community health centers }\end{array}$ & 5.5 \\
\hline $\begin{array}{l}\text { Jacques S, Edgard-Marius O, Bruno } \\
\text { D [31] }\end{array}$ & Benin & 2003 & Maternal & $1,735 / 100,000$ & 231 & $55-72$ & $\begin{array}{l}\text { Retrospective case record review at } 4 \text { referral } \\
\text { hospitals }\end{array}$ & 5 \\
\hline $\begin{array}{l}\text { Vangeenderhuysen C, Banos } \\
\mathrm{JP}, \text { Mahaman T [32] }\end{array}$ & Niger & 1993-1994 & Maternal & $1,547 / 100,000$ & 25 & 84 & $\begin{array}{l}\text { Prospective case record review, staff interviews, } \\
\text { and family interviews in a group of urban hospitals }\end{array}$ & 4 \\
\hline $\begin{array}{l}\text { El Amin S, Langhoff-Roos J, } \\
\text { Bodker B, et al. [33] }\end{array}$ & Sudan & 2000 & Perinatal & $82 / 1,000$ & 43 & $58-82$ & $\begin{array}{l}\text { Prospective external audit by multidisciplinary } \\
\text { team through case presentations and grading } \\
\text { forms at a maternity hospital }\end{array}$ & 7.5 \\
\hline $\begin{array}{l}\text { Mbaruku G, van Roosmalen J, } \\
\text { Kimondo I, et al. [34] }\end{array}$ & Tanzania & $2002-2004$ & Perinatal & $38 / 1,000$ & 200 & - & $\begin{array}{l}\text { Retrospective audit by case record review and } \\
\text { family interviews at a regional hospital }\end{array}$ & 5.5 \\
\hline $\begin{array}{l}\text { Bouvier-Colle MH, Ouedraogo C, } \\
\text { Dumont A [35] }\end{array}$ & West Africa & 1994-1996 & Maternal & $311 / 100,000$ & 55 & 69 & $\begin{array}{l}\text { Prospective survey using questionnaires and verbal } \\
\text { autopsy in } 6 \text { West African countries: Ivory Coast, Mali, } \\
\text { Niger, Mauritania, Burkina Faso, and Senegal. Deaths } \\
\text { occurred in hospitals, in health centers, and at home }\end{array}$ & 6 \\
\hline $\begin{array}{l}\text { Chigbu CO, Okezie OA, Odugu } \\
\text { BU [36] }\end{array}$ & Nigeria & 1999-2007 & Perinatal & $89 / 1,000$ & 316 & - & $\begin{array}{l}\text { Retrospective case record review, physician interview, } \\
\text { and midwife interview at a university teaching hospital }\end{array}$ & 3 \\
\hline van Roosmalen J [37] & Tanzania & 1971-1976 & Perinatal & $48 / 1,000$ & 137 & 25 & Retrospective case record review at a district hospital & 2 \\
\hline De Muylder X [38] & Zimbabwe & 1984-1986 & Perinatal & $31 / 1,000$ & 319 & 76 & $\begin{array}{l}\text { Prospective medical record review, family interviews, } \\
\text { laboratory evaluation, and necropsy at } 6 \text { peripheral } \\
\text { birth centers and a referral district hospital }\end{array}$ & 3 \\
\hline $\begin{array}{l}\text { Cham M, Vangen S, Sundby } \\
\text { J [39] }\end{array}$ & Gambia & 2002 & Maternal & $279 / 100,000$ & 42 & "Majority" & $\begin{array}{l}\text { Prospective medical record review, health worker } \\
\text { interviews, and verbal autopsy in one rural district } \\
\text { involving } 17 \text { birth facilities and one hospital }\end{array}$ & 6 \\
\hline $\begin{array}{l}\text { Dumont A, Tourigny C, Fournier } \\
\text { P [40] }\end{array}$ & Senegal & $2004-2005$ & Maternal & - & 69 & 48 & $\begin{array}{l}\text { Prospective medical record review, health worker } \\
\text { interviews, and family interviews at } 5 \text { referral hospitals }\end{array}$ & 7 \\
\hline Frost O [26] & Ethiopia & 1980 & Maternal & $780 / 100,000$ & 30 & - & $\begin{array}{l}\text { Prospective medical record review and health worker } \\
\text { interviews at a national referral hospital }\end{array}$ & 4 \\
\hline Frost $O[26]$ & Ethiopia & 1980 & Perinatal & $9 / 1,000$ & 291 & 8 & $\begin{array}{l}\text { Prospective medical record review and health worker } \\
\text { interviews at a national referral hospital }\end{array}$ & 4 \\
\hline Price TG [41] & Tanzania & 1983 & Maternal & $250 / 100,000$ & 115 & - & $\begin{array}{l}\text { Prospective case record review and questionnaires } \\
\text { in a region comprising of hospitals, health centers, } \\
\text { and dispensaries }\end{array}$ & 5 \\
\hline Adetoro OO [42] & Nigeria & 1972-1983 & Maternal & $450 / 100,000$ & 624 & - & $\begin{array}{l}\text { Retrospective medical record review at a national } \\
\text { referral center }\end{array}$ & 3 \\
\hline Bullough CH [43] & Malawi & 1977 & Maternal & $263 / 100,000$ & 109 & 88 & $\begin{array}{l}\text { Prospective questionnaires completed by physicians } \\
\text { and midwives at } 1 \text { central hospital, } 8 \text { district hospitals, } \\
6 \text { mission hospitals, and } 92 \text { rural birth facilities }\end{array}$ & 4 \\
\hline
\end{tabular}


Table 1 Summary of study datasets $(n=44)$ (Continued)

\section{Johnstone FD, Ochiel SO [44]}

Hinderaker SG, Olsen BE,

Bergsjo PB, et al. [45]

D'Ambruoso L, Byass $P$

Qomariyah SN, et al. [25]

D'Ambruoso L, Byass P

Qomariyah SN, et al. [25]

Hailu S, Enqueselassie F.

Berhane Y [46]

Issah K, Nang-Beifubah A,

Opoku CF [47]

Jafarey S, Rizvi T, Koblinsky M, et al. [48]

Kongnyuy E, Mlava G, van den Broek N [49]

Waiswa P, Kallander K, Peterson $\mathrm{S}$, et al. [50]

Sorensen BL, Elsass P, Nielsen $B B$, et al. [51]

Lori JR, Starke AE [52]

Granja AC, Machungo F,

Bergstrom S [53]

Granja AC, Machungo F,

Gomes, A, et al. [54]

Kidanto HL, Mogren I, van

Roosmalen J, et al. [55]

Olsen BE, Hinderaker SG,

Bergsjo P, et al. [56]

\section{Kenya}

Tanzania

1996-1996 Perinatal

$27 / 1,000$

393

Indonesia

2002-2006 Maternal

Burkina Faso

2002-2006 Maternal

Ethiopia

2005-2006 Maternal

Ghana

2009

Maternal

Pakistan

2005-2007 Maternal

Malawi

200

Uganda

2005-2008 Perinatal

Tanzania

Liberia

2008

Mozambique

1989-1990

Mozambique

1989-1993 Matern

2007

Perinatal

$\begin{array}{llll}\text { Tanzania } & \text { 1995-1996 Maternal } & - & 45\end{array}$
Retrospective case record review at a national referral hospital

Prospective interviews of antenatal care attendees

combined with retrospective household surveys using

verbal autopsy and medical records in 7 rural

communities. Deaths occurred at home and in rural health facilities.

Retrospective review of verbal autopsies in a

community with a district hospital and 19

health centers

Retrospective review of verbal autopsies in a

community with 5 hospitals and 66 health centers

Retrospective case record review and health worker interviews in 5 public hospitals

Prospective questionnaires completed by health workers in a community with 6 hospitals and 73 health centers

Retrospective and prospective verbal autopsy in two districts at the community and hospital levels

Prospective register review, referral note review, case record review, and family interviews in 9 hospitals

Retrospective case record review from volunteer collected data, and a standard verbal autopsy questionnaire. Study included home and hospital deaths.

Retrospective case record review, staff observations, and staff interviews at a regional hospital

Prospective case record review using a standard audit tool, combined with interviews conducted by trained nurses at the community and hospital level

Retrospective medical record review at an urban referral hospital

Retrospective medical record review at an urban referral hospital

52-75 Retrospective multidisciplinary audit panel of internal and external reviewers using a structured assessment protocol and grading form at a national hospital records, village leader reported deaths, household surveys and antenatal clinic records at the community and hospital level. Verbal autopsy questionnaires were also used. 
Table 1 Summary of study datasets $(n=44)$ (Continued)

\begin{tabular}{|c|c|c|c|c|c|c|c|c|}
\hline $\begin{array}{l}\text { Oladapo OT, Ariba AJ, } \\
\text { Odusoga OL [28] }\end{array}$ & Nigeria & 1999-2004 & Maternal & $\begin{array}{l}2508-2931 / \\
100,000^{*}\end{array}$ & 71 & - & $\begin{array}{l}\text { Retrospective case record review at tertiary care } \\
\text { hospital. Reviewed by committee of } 3 \text { consultants } \\
\text { and } 3 \text { residents. }\end{array}$ & 4 \\
\hline Byaruhanga RN [57] & Uganda & 1997-1998 & Perinatal & $68 / 1000$ & 235 & - & $\begin{array}{l}\text { Prospective case record review by a team comprised } \\
\text { of a pediatrician, obstetrician and three midwives at } \\
\text { a tertiary referral hospital }\end{array}$ & 5 \\
\hline De Muylder X [58] & Zimbabwe & 1985-1987 & Maternal & $137 / 100,000$ & 70 & 50 & $\begin{array}{l}\text { Retrospective case record review by a multidisciplinary } \\
\text { committee of deaths occurring at district and rural } \\
\text { hospitals }\end{array}$ & 3.5 \\
\hline Bhatt RV [24] & India & 1967-1968 & Maternal & $1,448 / 100,000$ & 43 & 10 & $\begin{array}{l}\text { Prospective case record review combined with staff } \\
\text { meetings and interviews of caregivers at a university } \\
\text { teaching hospital }\end{array}$ & 6 \\
\hline Bhatt RV [24] & India & 1967-1968 & Perinatal & $115 / 1,000$ & 342 & - & $\begin{array}{l}\text { Prospective case record review combined with staff } \\
\text { meetings and interviews of caregivers at a university } \\
\text { teaching hospital }\end{array}$ & 6 \\
\hline Bhatt RV [24] & India & 1983-1984 & Maternal & $1,152 / 100,000$ & 36 & 1.5 & $\begin{array}{l}\text { Prospective case record review combined with staff } \\
\text { meetings and interviews of caregivers at a university } \\
\text { teaching hospital }\end{array}$ & 6 \\
\hline Bhatt RV [24] & India & 1983-1984 & Perinatal & $101 / 1,000$ & 315 & - & $\begin{array}{l}\text { Prospective case record review combined with staff } \\
\text { meetings and interviews of caregivers at a university } \\
\text { teaching hospital }\end{array}$ & 6 \\
\hline Mbarku G, Bergstrom S [27] & Tanzania & 1984-1991 & Maternal & $\begin{array}{c}186-933 / \\
100,000^{*}\end{array}$ & 132 & - & $\begin{array}{l}\text { Retrospective and prospective case record review } \\
\text { with interventions in } 1986 \text { at a regional hospital }\end{array}$ & 3 \\
\hline $\begin{array}{l}\text { Steklenberg J, van Roosmalen } \\
\text { J [59] }\end{array}$ & Zambia & 1999-2001 & Maternal & $1,359 / 100,000$ & 15 & - & $\begin{array}{l}\text { Prospective case record review and regular maternal } \\
\text { mortality review meetings at a district hospital. }\end{array}$ & 4.5 \\
\hline $\begin{array}{l}\text { Ouedraogo C, Bouvier-Coller } \\
\text { MH [60] }\end{array}$ & $\begin{array}{l}\text { Burkinia Faso, Ivory Coast, } \\
\text { Mauritania, Mali, Niger } \\
\text { and Senegal }\end{array}$ & 1985-1997 & Maternal & $\begin{array}{l}\text { Variable by } \\
\text { country }\end{array}$ & 55 & - & $\begin{array}{l}\text { Retrospective case record review combined with } \\
\text { "verbal autopsy" using a questionnaires and a } \\
\text { multidisciplinary team review of all cases at the } \\
\text { hospital level }\end{array}$ & 5 \\
\hline Qazi GR [61] & Pakistan & 1992 & Maternal & - & 40 & - & $\begin{array}{l}\text { Retrospective case record review at a university } \\
\text { teaching hospital }\end{array}$ & 3 \\
\hline $\begin{array}{l}\text { Rachid B, Abouchadi S, de } \\
\text { Brouwere V, Belghiti A [62] }\end{array}$ & Morocco & 2009 & Maternal & - & 436 & 76 & $\begin{array}{l}\text { Retrospective case record review for healthcare } \\
\text { setting deaths, and verbal autopsy for home deaths }\end{array}$ & 2.5 \\
\hline
\end{tabular}

2 calculations covering two different time periods within a continuous time period. 
Table 2 Summary of the $\mathbf{4 2}$ avoidable factors, listed by category and in descending order of attributable deaths

\begin{tabular}{|c|c|c|c|}
\hline Health worker-oriented factors & Patient-oriented factors & Administrative/supply factors & Transport/ referral factors \\
\hline Substandard health worker practice & Patient delay & $\begin{array}{l}\text { Poor blood transfusion capacity } \\
\text { or inappropriate administration }\end{array}$ & $\begin{array}{l}\text { Unidentified lack or delay in } \\
\text { transport }\end{array}$ \\
\hline Delay in care on admission to birth facility & Poor antenatal care & Medication shortage & $\begin{array}{l}\text { Poor transport between } \\
\text { facilities }\end{array}$ \\
\hline Delayed operative delivery & Use of herbal medicine & General supply/ equipment shortage & $\begin{array}{l}\text { Poor transportation from } \\
\text { home to facility }\end{array}$ \\
\hline $\begin{array}{l}\text { Inadequate intrapartum monitoring of } \\
\text { mother/fetus }\end{array}$ & $\begin{array}{l}\text { Cultural inhibitions causing } \\
\text { delay in seeking care }\end{array}$ & Unsanitary environment & \\
\hline $\begin{array}{l}\text { Inadequate initial maternal assessment and } \\
\text { management }\end{array}$ & Financial constraints & Inadequate operating theatre facilities & \\
\hline $\begin{array}{l}\text { Unavailability of health worker for key } \\
\text { intervention }\end{array}$ & $\begin{array}{l}\text { No knowledge of danger } \\
\text { symptoms }\end{array}$ & & \\
\hline \multicolumn{4}{|l|}{ Poor communication between health workers } \\
\hline \multicolumn{4}{|l|}{ Missed or unskilled breech delivery } \\
\hline \multicolumn{4}{|l|}{ Substandard health worker antenatal care practices } \\
\hline \multicolumn{4}{|l|}{$\begin{array}{l}\text { Inadequate monitoring of mothers in } \\
\text { hypovolemic or septic shock }\end{array}$} \\
\hline \multicolumn{4}{|l|}{ Poor neonatal resuscitation } \\
\hline \multicolumn{4}{|l|}{$\begin{array}{l}\text { Inadequate management of hypertensive } \\
\text { related disorders }\end{array}$} \\
\hline \multicolumn{4}{|l|}{ Failure to diagnose/ treat neonatal infection } \\
\hline \multicolumn{4}{|l|}{ Failure to diagnose preterm labor } \\
\hline \multicolumn{4}{|l|}{ Failure to diagnose/ treat syphilis } \\
\hline \multicolumn{4}{|l|}{ Health worker related referral delay } \\
\hline \multicolumn{4}{|l|}{ Inadequate management of $3^{\text {rd }}$ stage of labor } \\
\hline \multicolumn{4}{|l|}{ Poor postpartum maternal monitoring } \\
\hline \multicolumn{4}{|l|}{ Inappropriate indication for operative delivery } \\
\hline \multicolumn{4}{|l|}{ Inadequate partogram usage } \\
\hline \multicolumn{4}{|l|}{ Failure to diagnose/treat maternal/fetal infection } \\
\hline \multicolumn{4}{|l|}{ Anesthesia complications during operative delivery } \\
\hline \multicolumn{4}{|l|}{ Inadequate response to poor labor progress } \\
\hline \multicolumn{4}{|l|}{ Inadequate action taken for fetal distress } \\
\hline \multicolumn{4}{|l|}{ Inadequate assessment of fetal distress } \\
\hline \multicolumn{4}{|l|}{ Inadequate assisted vaginal delivery } \\
\hline \multicolumn{4}{|l|}{ Inappropriate discharge when patient not well } \\
\hline Health worker industrial strike & & & \\
\hline
\end{tabular}

women's structure of social support and likelihood of institutional delivery [67].

The third most important avoidable factor by attributable deaths related to blood transfusion capacity. Specific reasons cited included lack of accessibility to a blood bank, lack of materials for blood collection, blood safety concerns, recruitment of donors, and lack of infrastructure. One typical example of limited blood transfusion capacity was noted in the study by Adetoro [42], in which it was described how the blood bank at their hospital is open only for 8 hours daily. At all other times, blood must be retrieved from the blood bank of a larger hospital, located 4 kilometers away. Not only was distance an issue, but the authors also found that the larger hospital's blood bank frequently suffered a lack of blood supply, and husbands and other relatives were unwilling to donate blood when asked.

The main limitation of this systematic review derives from limitations of the individual audits. As mentioned above, the assessment of avoidable factors in many cases would have benefited from a greater degree of granularity. For instance, factors such as "substandard health worker 
Table 3 Top 10 audit-identified avoidable factors in maternal and perinatal deaths

\begin{tabular}{|c|c|c|c|c|}
\hline Factor & Category & $\begin{array}{l}\text { Datasets in which factor was } \\
\text { an identified cause of death; } \\
n=44(\%)\end{array}$ & $\begin{array}{l}\text { Estimate of the factor's contribution } \\
\text { to deaths in datasets in which it } \\
\text { was identified; \% (CI) }\end{array}$ & $\begin{array}{l}\text { Total number of attributable } \\
\text { deaths due to factor in the } \\
\text { entire sample; } n=6205(\%)\end{array}$ \\
\hline Substandard health worker practice & Health worker-oriented factor & $18(40.9)$ & $28.5(19.5-39.7)$ & $688(11.1)$ \\
\hline Patient delay & Patient-oriented factor & $23(52.3)$ & $22.2(16.0-30.0)$ & $665(10.7)$ \\
\hline $\begin{array}{l}\text { Poor blood transfusion capacity or } \\
\text { inappropriate administration }\end{array}$ & Administrative/ supply factor & $21(47.7)$ & $24.9(18.5-32.6)$ & $634(10.2)$ \\
\hline Delay in care on admission to birth facility & Health worker-oriented factor & $20(45.5)$ & $26.6(18.5-36.6)$ & $628(10.1)$ \\
\hline Undefined lack of or delay in transport & Transport/ referral factor & $23(52.3)$ & $23.7(16.2-33.4)$ & $546(8.8)$ \\
\hline Delayed operative delivery & Health worker-oriented factor & $12(27.3)$ & $23.1(11.0-42.1)$ & $442(7.1)$ \\
\hline $\begin{array}{l}\text { Inadequate intrapartum monitoring of } \\
\text { mother/fetus }\end{array}$ & Health worker-oriented factor & $10(22.7)$ & $24.3(13.8-39.1)$ & $374(6)$ \\
\hline $\begin{array}{l}\text { Inadequate initial maternal assessment/ } \\
\text { management }\end{array}$ & Health worker-oriented factor & $10(22.7)$ & $20.0(10.5-34.7)$ & $339(5.5)$ \\
\hline Poor antenatal care & Patient-oriented factor & $11(25.0)$ & $14.3(7.0-27.0)$ & $301(4.9)$ \\
\hline $\begin{array}{l}\text { Unavailability of health worker for key } \\
\text { intervention }\end{array}$ & Health worker-oriented factor & $10(22.7)$ & $22.4(10.6-41.2)$ & $251(4)$ \\
\hline
\end{tabular}


practice" and "poor antenatal care" provide a broad orientation to where deficiencies in care occur, but greater specificity (e.g., what specific substandard heath worker practice took place? Why was antenatal care poor?) would provide more precise direction in order to successfully inform health solutions that target existing gaps in the health care system. Therefore, while the quantitative analyses presented are useful for helping to appreciate the relative frequencies with which avoidable factors were reported, the results of this study may have greater qualitative value through the description of where and when preventable deficiencies in care were reported to have occurred.

A second limitation was the lack of standardized audit forms used in the different studies included in this analysis. Only 25 studies used a standardized form within their own study and none of these were identical between studies. This likely resulted in differences regarding how factors were both identified and labeled.

A third limitation is that the analysis was limited to published datasets in the medical literature. As a result, the sample of deaths audited was not random. The majority of the datasets included were from Africa, and data were not weighted based on population size.

Finally, a limitation of this review is the number of datasets included. While the number of datasets identified was robust on an absolute scale, we were surprised that more did not exist given that the inclusion criteria were liberal in terms of study date (1965 onwards) and geography (any low- and lower-middle income country). Audits are a proven method for helping to improve quality of care relating to childbirth [68], and some countries, such as South Africa in particular, have taken pioneering efforts to incorporate audits into the national healthcare system $[12,13,18]$. The findings of this review that relatively so few audits are being conducted (or, at least, reported) globally could constitute a call to action for stakeholders to initiate mortality audit programs, particularly in settings where rates of maternal and perinatal deaths are high.

\section{Conclusions}

Audit processes highlight precisely where breakdowns in clinical care occur and are an established method for facilitating quality improvement in health systems. Through a systematic review of avoidable factors in maternal and perinatal mortality we are able to identify the specific timing and nature of factors that are reported to be associated with severe childbirth-related harm in low resource settings. These data can be used to inform the development of health system improvements that specifically target known deficiencies in care, which represents a rational approach for measurably improving health and achieving progress towards Millennium Development Goals Four and Five.

\section{Additional files}

Additional file 1: Preferred Reporting Items for Systematic Reviews and Meta-Analyses (PRISMA) Checklist.

Additional file 2: Estimate of contribution of substandard health worker practice to maternal and perinatal deaths.

\section{Abbreviations}

MDG: Millennium development goal; WHO: World Health Organization.

\section{Competing interests}

The authors declare that they have no competing interests.

\section{Authors' contributions}

HSM participated in developing the project, reviewed all of the manuscripts included in this study, carried out the data collection, and wrote the first version of the manuscript. SL and NH participated in developing the project, performed all of the statistical analysis, and wrote the statistical analysis section of the manuscript. AL, PA, and AAG participated in developing the project. JS participated in developing the project, reviewed all of the manuscripts included in this study, carried out the data collection, participated in writing the first version of the manuscript, and was responsible for coordinating the entire project. All authors read and approved the final manuscript.

\section{Acknowledgements}

The authors thank Grace Galvin (Harvard School of Public Health) and Paul Bain (Countway Library, Harvard Medical School) for their assistance with developing the search strategy and obtaining the articles to be reviewed.

\section{Author details}

${ }^{1}$ The Hospital for Sick Children, 555 University Avenue, Toronto, ON M5G 1X8, Canada. ${ }^{2}$ Center for Surgery and Public Health, Brigham and Women's Hospital, Boston, MA, USA. ${ }^{3}$ Ariadne Labs: A Joint Center at Brigham and Women's Hospital and Harvard School of Public Health, Boston, MA, USA. ${ }^{4}$ World Health Organization, Geneva, Switzerland. ${ }^{5}$ Harvard School of Public Health, Boston, MA, USA. ${ }^{6}$ MassGeneral Hospital for Children, Boston, MA, USA.

Received: 17 December 2013 Accepted: 5 August 2014

Published: 16 August 2014

\section{References}

1. Walker N, Yenokyan G, Friberg IK, Bryce J: Patterns in coverage of maternal, newborn, and child health interventions: projections of neonatal and under-5 mortality to 2035. Lancet 2013, 382(9897):1029-1038.

2. Bhutta ZA, Chopra M, Axelson H, Berman P, Boerma T, Bryce J, Bustreo F, Cavagnero E, Cometto G, Daelmans B, de Francisco A, Fogstad H, Gupta N, Laski L, Lawn J, Maliqi B, Mason E, Pitt C, Requejo J, Starrs A, Victora CG, Wardlaw T: Countdown to 2015 decade report (2000-10): taking stock of maternal, newborn, and child survival. Lancet 2010, 375(9730):2032-2044

3. Hogan MC, Foreman KJ, Naghavi M, Ahn SY, Wang M, Makela SM, Lopez $A D$, Lozano R, Murray CJ: Maternal mortality for 181 countries, 1980-2008: a systematic analysis of progress towards millennium development goal 5. Lancet 2010, 375(9726):1609-1623.

4. Rajaratnam JK, Marcus JR, Flaxman AD, Wang H, Levin-Rector A, Dwyer L, Costa M, Lopez AD, Murray CJ: Neonatal, postneonatal, childhood, and under-5 mortality for 187 countries, 1970-2010: a systematic analysis of progress towards millennium development goal 4. Lancet 2010, 375(9730):1988-2008.

5. Lawn JE, Blencowe H, Pattinson R, Cousens S, Kumar R, Ibiebele I, Gardosi J, Day LT, Stanton C: Stillbirths: where? when? why? how to make the data count? Lancet 2011, 377(9775):1448-1463.

6. Ronsmans C, Graham WJ: Maternal mortality: who, when, where, and why. Lancet 2006, 368(9542):1189-1200.

7. Lawn JE, Cousens S, Zupan J: 4 million neonatal deaths: when? where? why? Lancet 2005, 365(9462):891-900.

8. Mancey-Jones M, Brugha RF: Using perinatal audit to promote change: a review. Health Policy Plan 1997, 12(3):183-192. 
9. Pattinson R, Kerber K, Waiswa P, Day LT, Mussell F, Asiruddin SK, Blencowe H, Lawn JE: Perinatal mortality audit: counting, accountability, and overcoming challenges in scaling up in low- and middle-income countries. Int J Gynaecol Obstet 2009, 107(Suppl 1):S113-S121. S121-112.

10. Dumont A, Fournier P, Abrahamowicz M, Traore M, Haddad S, Fraser WD: Quality of care, risk management, and technology in obstetrics to reduce hospital-based maternal mortality in Senegal and Mali (QUARITE): a cluster-randomised trial. Lancet 2013, 382(9887):146-157.

11. Kidanto $H L$, Wangwe $P$, Kilewo CD, Nystrom L, Lindmark G: Improved quality of management of eclampsia patients through criteria based audit at Muhimbili National Hospital, Dar es Salaam, Tanzania. bridging the quality gap. BMC Pregnancy Childbirth 2012, 12:134.

12. Bradshaw D, Chopra M, Kerber K, Lawn JE, Bamford L, Moodley J, Pattinson R, Patrick M, Stephen C, Velaphi S: Every death counts: use of mortality audit data for decision making to save the lives of mothers, babies, and children in South Africa. Lancet 2008, 371(9620):1294-1304.

13. Saving Mothers 2008-2010: Fifth report on the confidential enquiries into maternal deaths in South Africa. http://www.hst.org.za/sites/default/ files/savingmothersshort.pdf.

14. Pattinson RC: Saving Babies: A Perinatal Care Survey of South Africa 2000 Executive Summary. Pretoria, South Africa: The MRC Unit for Maternal and Infant Health Care Strategies; 2000.

15. World Bank: World Development Indicators. Washington, DC: World Bank; 2011.

16. World Health Organization: health statistics and information systems. http://www.who.int/healthinfo/statistics/indmaternalmortality/en/.

17. World Health Organization: maternal, newborn, child and adolescent health. http://www.who.int/maternal_child_adolescent/topics/maternal/ maternal_perinatal/en/

18. Saving babies 2003-2005: fifth perinatal care survey of South Africa. http://bettercare.co.za/wp-content/uploads/2013/01/Saving-Babies-20032005.pdf.

19. Aveyard $\mathrm{H}$ : Doing a Literature Review in Health and Social Care: A Practical Guide. 2nd edition. New York: Open University Press; 2010.

20. Pirkle CM, Dumont A, Zunzunegui MV: Criterion-based clinical audit to assess quality of obstetrical care in low- and middle-income countries: a systematic review. Int J Qual Health Care 2011, 23(4):456-463.

21. Chang BH, Waternaux C, Lipsitz S: Meta-analysis of binary data: which within study variance estimate to use? Stat Med 2001, 20(13):1947-1956.

22. DerSimonian R, Laird N: Meta-analysis in clinical trials. Control Clin Trials 1986, 7(3):177-188

23. Liberati A, Altman DG, Tetzlaff J, Mulrow C, Gotzsche PC, loannidis JP, Clarke M, Devereaux PJ, Kleijnen J, Moher D: The PRISMA statement for reporting systematic reviews and meta-analyses of studies that evaluate healthcare interventions: explanation and elaboration. BMJ 2009, 339:b2700.

24. Bhatt RV: Professional responsibility in maternity care: role of medical audit. Int J Gynaecol Obstet 1989, 30(1):47-50.

25. D'Ambruoso L, Byass P, Qomariyah SN, Ouedraogo M: A lost cause? extending verbal autopsy to investigate biomedical and socio-cultura causes of maternal death in Burkina Faso and Indonesia. Soc Sci Med 2010, 71(10):1728-1738.

26. Frost O: Maternal and perinatal deaths in an Addis Ababa Hospital, 1980. Ethiop Med J 1984, 22(3):143-146.

27. Mbaruku G, Bergstrom S: Reducing maternal mortality in Kigoma, Tanzania. Health Policy Plan 1995, 10(1):71-78.

28. Oladapo OT, Ariba AJ, Odusoga OL: Changing patterns of emergency obstetric care at a Nigerian University hospital. Int J Gynaecol Obstet 2007, 98(3):278-284

29. Ozumba BC, Nwogu-Ikojo EE: Avoidable maternal mortality in Enugu, Nigeria. Public Health 2008, 122:354-360.

30. Supratikto G, Wirth ME, Achadi E, Cohen S, Ronsmans C: A district-based audit of the causes and circumstances of maternal deaths in South Kalimantan, Indonesia. Bull World Health Organ 2002, 80(3):228-234

31. Jacques S, Edgard-Marius O, Bruno D: Maternal deaths audit in four Benin referral hospitals: quality of emergency care causes and contributing factors. Afr J Reprod Health 2006, 10:28-40.

32. Vangeenderhuysen C, Banos JP, Mahaman T: Preventable maternal mortality in an urban area in Niamey (Niger). Sante 1995, 5:49-54

33. El Amin S, Langhoff-Roos J, Bødker B, Bakr AA, Ashmeig AL, Ibrahim SA, Lindmark G: Introducing qualitative perinatal audit in a tertiary hospital in Sudan. Health Policy Plan 2002, 17:296-303.
34. Mbaruku G, van Roosmalen J, Kimondo I, Bilango F, Bergström S: Perinatal audit using the 3-delays model in western Tanzania. Int J Gynaecol Obstet 2009, 106:85-88.

35. Bouvier-Colle MH, Ouedraogo C, Dumont A, Vangeenderhuysen C, Salanave $B$, Decam C: Maternal mortality in West Africa. rates, causes and substandard care from a prospective survey. Acta Obstet Gynecol Scand 2001, 80:113-119.

36. Chigbu CO, Okezie OA, Odugu BU: Intrapartum stillbirth in a Nigerian tertiary hospital setting. Int J Gynaecol Obstet 2009, 104:18-21.

37. Van Roosmalen J: Perinatal mortality in rural Tanzania. Br J Obstet Gynaecol 1989, 96:827-834.

38. De Muylder X: Perinatal mortality audit in a Zimbabwean district. Paediatr Perinat Epidemiol 1989, 3:284-293.

39. Cham M, Vangen S, Sundby J: Maternal deaths in rural Gambia. Glob Public Health 2007, 2:359-372

40. Dumont A, Tourigny C, Fournier P: Improving obstetric care in low-resource settings: implementation of facility-based maternal death reviews in five pilot hospitals in Senegal. Hum Resour Health 2009, 7:61

41. Price TG: Preliminary report on maternal deaths in the Southern Highlands of Tanzania in 1983. J Obstet Gynaecol East Cent Africa 1984, 3:103-110.

42. Adetoro OO: Maternal mortality-a twelve-year survey at the University of Ilorin Teaching Hospital (U.I.T.H.) Ilorin, Nigeria. Int J Gynaecol Obstet 1987, 25(2):93-98.

43. Bullough $\mathrm{CH}$ : Analysis of maternal deaths in the Central Region of Malawi. East Afr Med J 1981, 58:25-36.

44. Johnstone FD, Ochiel SO: Perinatal mortality at Kenyatta National Hospital, Nairobi. East Afr Med J 1980, 57:119-123.

45. Hinderaker SG, Olsen BE, Bergsjo PB, Gasheka P, Lie RT, Havnen J, Kvale G: Avoidable stillbirths and neonatal deaths in rural Tanzania. Bjog 2003, 110(6):616-623.

46. Hailu S, Enqueselassie F, Berhane Y: Health facility-based maternal death audit in Tigray, Ethiopia. Ethiop J Heal Dev 2009, 23:115-119.

47. Issah K, Nang-Beifubah A, Opoku CF: Maternal and neonatal survival and mortality in the Upper West Region of Ghana. Int J Gynaecol Obstet 2011 113:208-210.

48. Jafarey SN, Rizvi T, Koblinsky M, Kureshy N: Verbal autopsy of maternal deaths in two districts of Pakistan-filling information gaps. $J$ Health Popul Nutr 2009, 27(2):170-183

49. Kongnyuy EJ, Mlava G, van den Broek N: Facility-based maternal death review in three districts in the central region of Malawi: an analysis of causes and characteristics of maternal deaths. Womens Health Issues 2009, 19:14-20.

50. Waiswa P, Kallander K, Peterson S, Tomson G, Pariyo GW: Using the three delays model to understand why newborn babies die in eastern Uganda. Trop Med Int Health 2010, 15:964-972.

51. Sorensen BL, Elsass P, Nielsen BB, Massawe S, Nyakina J, Rasch V: Substandard emergency obstetric care - a confidential enquiry into maternal deaths at a regional hospital in Tanzania. Trop Med Int Health 2010, 15:894-900.

52. Lori JR, Amable EE, Mertz SG, Moriarty K: Behavior change following implementation of home-based life-saving skills in Liberia, West Africa. J Midwifery Womens Health 2012, 57:495-501.

53. Granja AC, Machungo F, Bergstrom S: Avoidability of maternal death in Mozambique: audit and retrospective risk assessment in 106 consecutive cases. Afr J Health Sci 2000, 7:83-87.

54. Granja AC, Machungo F, Gomes A, Bergström S: Adolescent maternal mortality in Mozambique. J Adolesc Health 2001, 28:303-306.

55. Kidanto HL, Mogren I, van Roosmalen J, Thomas AN, Massawe SN, Nystrom $\mathrm{L}$, Lindmark G: Introduction of a qualitative perinatal audit at Muhimbili National Hospital, Dar es Salaam, Tanzania. BMC Pregnancy Childbirth 2009, 9:45

56. Olsen BE, Hinderaker SG, Bergsjo P, Lie RT, Olsen OH, Gasheka P, Kvale G: Causes and characteristics of maternal deaths in rural northern Tanzania. Acta Obstet Gynecol Scand 2002, 81(12):1101-1109.

57. Byaruhanga RN: Improving healthcare by perinatal mortality audit and feedback. Trop Doct 2000, 30:94-97.

58. De Muylder X: Maternal mortality audit in a Zimbabwean province. Arch Gynecol Obstet 1990, 247:131-138.

59. Stekelenburg J, van Roosmalen J: The maternal mortality review meeting: experiences from Kalabo District Hospital, Zambia. Trop Doct 2002, 32:219-223. 
60. Ouédraogo C, Bouvier-Colle MH: Maternal mortality in West Africa: risk rates, and rationale. J Gynecol Obstet Biol Reprod (Paris) 2002, 31:80-89.

61. Qazi G: Maternal mortality: an audit. J Coll Physicians Surg Pak 1998, 9:251-256.

62. Rachid B, Abouchadi S, de Brouwere V: Implementation and outcomes of a national maternal mortality monitoring system in Morocco 2008-2009. Trop Med Int Health 2011, 16:54.

63. Lim SS, Dandona L, Hoisington JA, James SL, Hogan MC, Gakidou E: India's Janani Suraksha Yojana, a conditional cash transfer programme to increase births in health facilities: an impact evaluation. Lancet 2010, 375(9730):2009-2023.

64. Rana TG, Chataut BD, Shakya G, Nanda G, Pratt A, Sakai S: Strengthening emergency obstetric care in Nepal: the Women's Right to Life and Health Project (WRLHP). Int J Gynaecol Obstet 2007, 98(3):271-277.

65. Powell-Jackson T, Morrison J, Tiwari S, Neupane BD, Costello AM: The experiences of districts in implementing a national incentive programme to promote safe delivery in Nepal. BMC Health Serv Res 2009, 9:97.

66. Ekirapa-Kiracho E, Waiswa P, Rahman MH, Makumbi F, Kiwanuka N, Okui O, Rutebemberwa E, Bua J, Mutebi A, Nalwadda G, Serwadda D, Pariyo GW, Peters DH: Increasing access to institutional deliveries using demand and supply side incentives: early results from a quasi-experimental study. BMC Int Health Hum Rights 2011, 11(Suppl 1):S11.

67. Ono M, Matsuyama A, Karama M, Honda S: Association between social support and place of delivery: a cross-sectional study in Kericho, Western Kenya. BMC Pregnancy Childbirth 2013, 13:214

68. Bugalho $A$, Bergstrom S: Value of perinatal audit in obstetric care in the developing world: a ten-year experience of the Maputo model. Gynecol Obstet Invest 1993, 36(4):239-243.

doi:10.1186/1471-2393-14-280

Cite this article as: Merali et al:: Audit-identified avoidable factors in maternal and perinatal deaths in low resource settings: a systematic review. BMC Pregnancy and Childbirth 2014 14:280.

\section{Submit your next manuscript to BioMed Central and take full advantage of:}

- Convenient online submission

- Thorough peer review

- No space constraints or color figure charges

- Immediate publication on acceptance

- Inclusion in PubMed, CAS, Scopus and Google Scholar

- Research which is freely available for redistribution 